Revista Brasileira de Meteorologia, v. 30, n. 4, 371 - 380, 2015

http://dx.doi.org/10.1590/0102-778620140149

\title{
CHARACTERIZATION OF HUMAN THERMAL COMFORT IN URBAN AREAS OF BRAZILIAN SEMIARID
}

\section{PEDRO VIEIRA DE AZEVEDO ${ }^{1}$, PÉRICLES TADEU DA COSTA BEZERRA ${ }^{2}$, MÁRIO DE MIRANDA VILAS BOAS RAMOS LEITÃO ${ }^{3}$, CARLOS ANTONIO COSTA DOS SANTOS ${ }^{1}$}

${ }^{1}$ Universidade Federal de Campina Grande, Unidade Acadêmica de Ciências Atmosféricas, Campina Grande, PB, Brasil

${ }^{2}$ Ministério do Planejamento, Orçamento e Gestão, Brasília, DF, Brasil

${ }^{3}$ Universidade Federal do Vale do São Francisco, Colegiado Acadêmico de Engenharia Agrícola (UNIVASF/CAEA), Juazeiro, BA, Brasil

azevedopedrovieira@gmail.com, carlos.santos@ufcg.edu.br, carlostorm@gmail.com, pericles.bezerra@dnit. gov.br, mario.miranda@univasf.edu.br.

Received November 2014 - Accepted March 2015

\begin{abstract}
Experimental studies were conducted aiming to characterize the thermal conditions in urban areas of the Brazilian semiarid for identifying the level of human thermal comfort in urban areas of the municipalities of Mossoró-RN, Serra Talhada-PE, Petrolina-PE and Juazeiro-BA. The results showed that the constituent elements of urban areas contribute to human thermal discomfort index $\left(\mathrm{DI}_{\mathrm{T}}\right)$. Both the wet and dry seasons showed up an uncomfortable condition in Mossoró on May 15th and on 23rd, 2008 (rural area) and on May 25rd, 2008 (urban area). By applying Thom's equation for obtaining the $\mathrm{DI}_{\mathrm{T}}$, it was observed that the urban areas reported thermal comfort conditions always inferior to those observed in the rural areas. The results indicate conditions of partial comfort for the all areas surveyed. However, the incidence of human thermal discomfort related to the minimum, average and maximum air temperatures are, probably associated to the formation of urban heat islands. In addition, the afforestation is an effective mechanism of mitigating the adverse effects of these structures with better quality of life to the population. Therefore, it can be stated that the Brazilian semiarid region has specific urban climate, which is influenced by the design characteristics of the urban structure and buildings.
\end{abstract}

Keywords: urban and rural areas, air temperature and humidity, human thermal discomfort index.

\section{RESUMO: CARACTERIZAÇÃO DO CONFORTO TÉRMICO HUMANO EM ÁREAS URBANAS} DO SEMIÁRIDO BRASILEIRO

Estudos experimentais foram realizados com o objetivo de caracterizar as condições térmicas em áreas urbanas do semiárido brasileiro para identificar o nível de conforto térmico dos municípios de Mossoró-RN, Serra Talhada-PE, Petrolina-PE e Juazeiro-BA. Os resultados mostraram que os elementos constitutivos de áreas urbanas contribuem para índice de desconforto térmico $\left(\mathrm{DI}_{\mathrm{T}}\right)$. Nas estações secas e úmidas foram observadas condições desconfortáveis em Mossoró. Ao aplicar a equação de Thom para a obtenção do $\mathrm{DI}_{\mathrm{T}}$, observou-se que as áreas urbanas relataram condições de conforto térmico sempre inferiores às observadas nas áreas rurais. Os resultados indicam condições de conforto parcial para as todas as regiões pesquisadas. No entanto, a incidência de desconforto térmico relacionada com as temperaturas mínima, média e máxima do ar são, provavelmente associadas à formação de ilhas de calor urbanas. Além disso, a arborização é um mecanismo eficaz na mitigação dos efeitos adversos destas estruturas com melhor qualidade de vida à população. Portanto, pode-se afirmar que a região do semiárido brasileiro tem clima urbano específico, que é influenciada pelas características dos projetos da estrutura urbana e edifícios.

Palavras-chave: áreas urbanas e rurais, temperatura e umidade do ar, índice de desconforto térmico humano. 


\section{INTRODUCTION}

Blazejczyk et al. (2012) affirms that in the last century there has been much active research on how to define human thermal comfort which resulted in various models. A large number of indices have been proposed, which are (or were) in use throughout the world. Some studies, such as Goldreich (1995), Ichinose et al. (1999) and Silva et al. (2010) showed that urban climate has been widely studied in many parts of the world, and the heat island phenomenon has been discussed, along with its impacts on the urban thermal environment. Similarly, the assessment of the effects of urbanization on human thermal comfort has been also studied by several researchers, for example: Burian and Shepherd (2005), Stathopoulos et al. (2004) and Sarrat et al. (2006).

Thermal comfort expresses satisfaction with the thermal environment, which is assessed by evaluating both objective and subjective parameters. The environmental conditions for reaching a sense of thermal comfort vary with the individual, once people have physiological and psychological differences. When the thermal environmental conditions exceed certain ranges, the human body thermoregulatory mechanisms are activated in order to maintain constant internal body temperature. Temperatures beyond the limits of comfort may cause thermal fatigue, and consequently, malaise, reduction of work performance, total loss of ability to perform intellectual activities, health problems and even death (Lamberts, 2014).

The human activities cause changes in the atmospheric composition and triggers climate change studies that form in the cities, called urban climate, which constitutes one of the most relevant factors for the environmental quality of the built environment (Coltri et al., 2007). The interurban climatic conditions are directly related to the heterogeneity of land use and urban features, generating heat islands and wet and dry islands (Viana and Amorim, 2008). Significant changes were observed in the urban atmosphere in Campina Grande-PB because of intense urbanization (Sousa Júnior, 2006; Silva et al., 2010). According to Johansson (2006), in hot and dry climates, a compact urban model is preferable. However, if there is a cold season, this urban model must include some wider or open spaces to provide access to solar radiation. In search for alternatives to offer human thermal comfort in environments already built, Alexandria and Jonesb (2008) found a reduction of temperature, improved thermal comfort, and energy savings by covering roofing and walls with some vegetation. Thus, thermal comfort can be approached on the basis of human and environmental variables (Nicol and Humphreys, 2002; Barbosa et al., 2003; Corbella and Yannas, 2003; Lamberts, 2014; Kwok and Chun, 2003 and Prado and Ferreira, 2005).
In the Brazilian semiarid region, the development of some cities, particularly those of medium size, helps to explain how changes in their urban structures, especially the coating of public roads in downtown areas, lead to experience temperature rise from the surrounding areas (Oke, 1991; Monteiro and Alucci, 2005; Bezerra et al., 2013). Temperature differences between the city and its surroundings, caused by environmental differences between urban and rural areas form currents of rising air moving from the urban periphery to the most heated areas, conducting air pollutants generated in the periphery to the urban center. These pollutants will be added to the existing urban center, intensifying the problem of environmental degradation in urban centers. Therefore, the already adverse natural conditions of the semiarid region are worsened by the building blocks of urban structures that contribute more markedly to worsen the quality of life in urban centers with increased thermal discomfort for the city population (Bezerra, 2009).

The Brazilian semiarid low latitudes are responsible for higher temperatures in cities, together with the land use and land cover changes cause modifications in energy balance, evidenced by the generation of heat islands (Perez et al., 2001; Azevedo and Tarifa, 2001; Kalnay and Cai, 2003; Monteiro and Mendonça, 2003 and Silva et al., 2010). Studies of energy balance in urban areas have shown that, contrary to what occurs in natural areas, the sensible heat flux has to be much higher than the latent heat flux, causing an increase in temperature compared with the rural environment (Oke et al., 1992). Recognizing the regional uncertainties on global climate models, several initiatives have emphasized the analyses focusing on smaller scales as boundary conditions for the production of more detailed scenarios (Silva Dias and Silva Dias, 2007).

In this context, knowledge of urban climate provides information for cities spatial management and planning, through technical, economic and political scenarios that can contribute to sustainable development (Grimmond et al., 2010; Kithiia and Dowling, 2010 and Mills et al., 2010). Given the above, this study aimed to characterize the human thermal conditions in urban areas of the Brazilian semiarid, to identify the level of human thermal comfort in urban areas of the municipalities of Mossoró-RN, Serra Talhada-PE, Petrolina-PE and Juazeiro-BA.

\section{MATERIAL AND METHODS}

\subsection{Areas of study and Instrumentation}

The experiments were conducted in the municipalities of Mossoró-RN (Area: 2,108.9 km² and Population: 259,815 inhabitants.), Serra Talhada-PE (Area: 2,979.9 km² and Population: 79,241 inhabitants), Petrolina-PE (area: 4,756.8 km² and Population: 294,081 inhabitants) and Juazeiro-BA (area: 


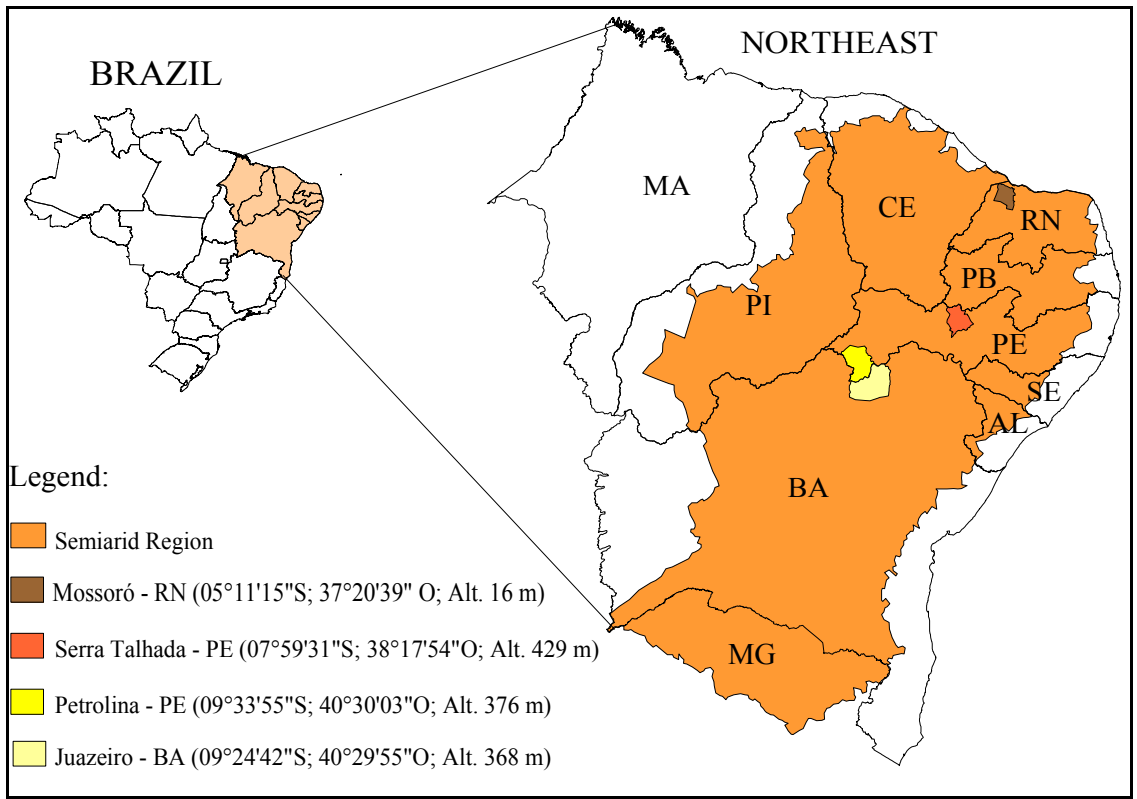

Figure 1 - Geographical location of the studied areas.

6,389 $\mathrm{km}^{2}$ and Population: 197,965 inhabitants), all inserted in the Brazilian semiarid region (Figure 1). These municipalities have the following climatic characteristics:

Mossoro: Very hot and dry climate with the rainy season from February to May, average annual temperature of 27.6 ${ }^{\circ} \mathrm{C}$, annual rainfall of $772.7 \mathrm{~mm}$ and average annual relative humidity of $68.3 \%$;

Serra Talhada: Semiarid climate with rainy season from November to April, average annual temperature of $25.2^{\circ} \mathrm{C}$, annual rainfall of $381.5 \mathrm{~mm}$, average annual relative humidity of $47.4 \%$;

Petrolina: Very dry and semi-arid climate with rainy season from November to April, average annual temperature of $25.2{ }^{\circ} \mathrm{C}$, annual rainfall of $479 \mathrm{~mm}$, average annual relative humidity of $50.2 \%$;

Juazeiro: Dry and hot climate with a high risk of drought and with rainy season from November to April, average annual temperature of $25.9^{\circ} \mathrm{C}$, annual rainfall of $430 \mathrm{~mm}$, average annual relative humidity of $53.4 \%$.

An automatic weather station was installed in the main public square in downtown of each municipality, with absence of obstacles around, for measuring temperature and relative humidity, wind speed and direction and rainfall for the periods: wet (May $12^{\text {th }}$ to $26^{\text {th }}, 2008$ ) and dry (November $15^{\text {th }}$ to December $\left.5^{\text {th }}, 2008\right)$. The sensors were coupled to automatic data collection systems (CR-10X data logger, Campbell), programmed to collect data every 2 seconds, providing average every 30 minutes and extreme values every 24 hours report. Data obtained in the different observational sites have been compared to each other and to those representing the natural condition without influence of urbanization, collected at weather stations located in a rural area of each municipality analyzed.

\subsection{METHODOLOGY}

The degree of thermal comfort was obtained by adapting the discomfort index of Thom $\left(\mathrm{DI}_{\mathrm{T}}\right.$ ), as follows (Monteiro and Alucci, 2005):

$$
D I_{T}=T_{a}-\left(0,55-0,0055 R H_{a}\right)\left(T_{a}-14,5\right)
$$

Where $\mathrm{T}_{\mathrm{a}}$ is the air temperature $\left({ }^{\circ} \mathrm{C}\right)$ and $\mathrm{RH}_{\mathrm{a}}$ the relative humidity (\%).

For all studied areas, it was observed an inverse relationship between air temperature and relative humidity, i.e., the maximum air temperature occurs at times very close to those of the minimum relative humidity. Similarly, the minimum air temperature occurs at times close to those of maximum relative humidity. Thus, it was possible to split the calculation of $\mathrm{DI}_{\mathrm{T}}$ into two components:

$$
\begin{aligned}
& \left(D I_{T}\right)_{x}=T_{x}-\left(0,55-0,0055 R H_{m}\right)\left(T_{x}-14,5\right) \\
& \left(D I_{T}\right)_{m}=T_{m}-\left(0,55-0,0055 R H_{x}\right)\left(T_{m}-14,5\right)
\end{aligned}
$$

Where $\left(\mathrm{DI}_{T}\right)_{\mathrm{x}}$ is the maximum thermal discomfort index $\left({ }^{\circ} \mathrm{C}\right), \mathrm{T}_{\mathrm{x}}$ the maximum air temperature $\left({ }^{\circ} \mathrm{C}\right), \mathrm{RH}_{\mathrm{m}}$ the minimum relative humidity $(\%),\left(\mathrm{DI}_{\mathrm{T}}\right)_{\mathrm{m}}$ the minimum thermal discomfort index $\left({ }^{\circ} \mathrm{C}\right), \mathrm{T}_{\mathrm{m}}$ the minimum air temperature $\left({ }^{\circ} \mathrm{C}\right)$ and $\mathrm{RH}_{\mathrm{x}}$ the maximum relative humidity (\%). 
The information in Table 1 were used to classify the level of thermal discomfort (Silva et al., 2010). To enable an effective comparison of data obtained in different localities surveyed, all recorded in field experiments (in clock time) were converted to true solar time, considering the corrections of time equation $\left(E_{t}\right)$ and the differences of longitude $(\lambda)$ as follows:

$$
t_{a}=t_{c}+\Delta \lambda+E_{t}
$$

Where $t_{a}$ is the apparent time (true solar time); $t_{c}$ is the civil time (clock time); $\Delta \lambda$ is the correction due to different longitudes:

$$
\begin{aligned}
\Delta \lambda & =4\left(\lambda_{s}-\lambda_{l}\right) \\
\mathrm{Et}= & 7.5 \times 10^{-5}+1.87 \times 10^{-3} \cos (\Gamma)-3.21 \times 10^{-2} \operatorname{sen}(\Gamma) \\
& -1.46 \times 10^{-2} \cos (2 \Gamma)-4.09 \times 10^{-2} \operatorname{sen}(2 \Gamma)
\end{aligned}
$$

Where $\lambda_{\mathrm{s}}$ is the standard meridian of longitude; $\lambda_{1}$ is the local longitude, and

$$
\Gamma=\left(\frac{360}{365}\right)(d-1)
$$

$\mathrm{d}=$ day of the year.

\section{RESULTS AND DISCUSSION}

Mean and extreme (maximum and minimum) values of air temperature, relative humidity and wind speed were analyzed for wet (May $12^{\text {th }}$ to $26^{\text {th }}, 2008$ ) and dry (November $15^{\text {th }}$ to
December $\left.5^{\text {th }}, 2008\right)$ periods beyond comparisons between rural and urban areas of each city studied.

\subsection{Air Temperature}

\section{a) Wet period}

By analyzing the data of the wet period (Table 2), it appears that the air temperature $(\mathrm{Ta})$ in urban areas was on average higher than that observed in rural areas in all districts and the urban area of Mossoró presented increased overall average (29.0 $\left.{ }^{\circ} \mathrm{C}\right)$. Moreover, the urban area of Serra Talhada was the largest absolute value of air temperature $\left(38.2^{\circ} \mathrm{C}\right)$. In this same area, with the largest temperature range of $18.9^{\circ} \mathrm{C}$ difference between the maximum and minimum air temperatures, was also observed. However, the urban area of Mossoró had the highest average maximum temperature $\left(\mathrm{T}_{\mathrm{x}}=35.5^{\circ} \mathrm{C}\right)$. The rural area registered the lowest minimum air temperature absolute values of $17.7^{\circ} \mathrm{C}$ and $20.1^{\circ} \mathrm{C}$ for Petrolina and Serra Talhada, respectively, while the rural area of Serra Talhada had the lowest mean minimum air temperature $\left(\mathrm{Tm}=20.1{ }^{\circ} \mathrm{C}\right)$. Occurrences of lower temperatures were observed during the time-period from 5 to $6 \mathrm{a}$.m. while the higher air temperatures occurred between 14 and 15 p.m.

\section{b) Dry period}

During the dry period (Table 3), it was observed that the air temperature in the urban area was, on average, higher than

\begin{tabular}{|c|c|c|c|c|c|c|c|}
\hline \multirow{3}{*}{ Station } & \multicolumn{7}{|c|}{ Air temperature $\left({ }^{\circ} \mathrm{C}\right)$} \\
\hline & \multicolumn{3}{|c|}{$\operatorname{Minimum}\left(T_{m}\right)$} & \multicolumn{3}{|c|}{ Maximum $\left(T_{x}\right)$} & \multirow{2}{*}{$\begin{array}{c}\text { Overall } \\
\text { Average }\end{array}$} \\
\hline & Time & Absolute & Mean & Time & Absolute & Mean & \\
\hline Mossoró (urban) & 04:56 & 22.4 & 24.5 & $14: 51$ & 36.9 & 35.5 & 29.0 \\
\hline Mossoró (rural) & 05:37 & 21.9 & 23.7 & $14: 47$ & 36.3 & 34.8 & 28.5 \\
\hline Serra Talhada (urban) & $06: 24$ & 19.3 & 21.1 & $15: 12$ & 38.2 & 32.4 & 25.7 \\
\hline Serra Talhada (rural) & 05:14 & 18.5 & 20.1 & $15: 19$ & 32.3 & 30.1 & 24.2 \\
\hline Petrolina (urban) & 05:56 & 20.4 & 22.4 & $14: 52$ & 37.9 & 33.5 & 27.0 \\
\hline Petrolina (rural) & 05:59 & 17.7 & 20.6 & $15: 05$ & 35.3 & 31.2 & 25.3 \\
\hline Juazeiro (urban) & 06:05 & 19.9 & 21.7 & $15: 10$ & 36.0 & 31.8 & 26.0 \\
\hline Juazeiro (rural) & 05:54 & 18.4 & 21.3 & $15: 03$ & 35.4 & 31.3 & 25.7 \\
\hline
\end{tabular}

Table 1 - Classes of thermal discomfort due to the Thom's thermal discomfort index $\left(\mathrm{DI}_{\mathrm{T}}\right)$.

\begin{tabular}{ccc}
\hline Level & Range of $\mathbf{D I}_{\mathbf{T}}\left(\mathbf{~}^{\mathbf{0}} \mathbf{C}\right)$ & Classes of thermal discomfort \\
\hline 1 & $\mathrm{DI}_{\mathrm{T}} \leq 14,9$ & uncomfortable \\
2 & $15,0 \leq \mathrm{DI}_{\mathrm{T}} \leq 19,9$ & comfortable \\
3 & $20,0 \leq \mathrm{DI}_{\mathrm{T}} \leq 26,4$ & partial comfort \\
4 & $\mathrm{DI}_{\mathrm{T}} \geq 26,5$ & uncomfortable \\
\hline
\end{tabular}

Table 2 - Air temperature: minimum (mean and absolute values and times of occurrence), maximum (mean and absolute values and times of occurrence) and overall average in the wet season. 
that observed in rural areas in all municipalities. In addition, it was observed that the urban area of Serra Talhada had the highest average $\left(30.0^{\circ} \mathrm{C}\right)$ and the highest absolute value of the air temperature $\left(39.0^{\circ} \mathrm{C}\right)$ during the period. In the rural area of Serra Talhada occurred the lowest mean minimum temperature (22.0 $\left.{ }^{\circ} \mathrm{C}\right)$. However, it was in the urban area of Petrolina that registered the lowest absolute value for this climate variable $\left(20.6{ }^{\circ} \mathrm{C}\right)$. The largest thermal amplitude occurred in rural area of Serra Talhada with $17.7^{\circ} \mathrm{C}$ difference between $T_{x}$ and $T_{m}$. The occurrence of lower temperatures were always observed at the times between 4 and 7 a.m. while the higher air temperatures occurred at between 1:00 and 4:00 pm. These results are in agreement with the climatology of the region, as described in the Section 2.1.

\subsection{Relative humidity}

\section{a) Wet period}

The relative humidity results obtained during the wet period are summarized in Table 4. It is observed, that in the course of this period, the maximum relative humidity $\left(\mathrm{RH}_{\mathrm{x}}\right)$ was, on average, more than $78.5 \%$ in all the surveyed localities.
This climatic variable was on average lower in the urban than in rural environments in Mossoró, Serra Talhada and Petrolina. In Juazeiro, probably due to wind currents arising from the São Francisco River, the urban area presented a relative humidity average slightly higher than that observed in rural area. The absolute maximum relative humidity always occurred at times between 5:00 and 8:00 am while the minimum relative humidity occurred between 2:00 and 4:30 pm.

It is worth noting that the occurrence of extreme values of relative humidity has a direct impact on thermal comfort, since rates above $90 \%$ hinders respiration while less than $40 \%$ levels are harmful to human health and the occurrences of values lower than this moisture level were observed in the four cities studied. The urban area of Mossoró presented, on average, the lowest values of relative humidity $(36.0 \%)$ while in absolute terms the lowest rate recorded during this period was $23.3 \%$ in the urban area of Petrolina.

\section{b) Dry period}

The results of the dry period are summarized in Table 5, in which one can observe that the maximum relative humidity

Table 3 - Air temperature: minimum (mean and absolute values and times of occurrence), maximum (mean and absolute values and times of occurrence) and overall average in the dry season.

\begin{tabular}{lccccccc}
\hline \multirow{2}{*}{\multicolumn{1}{c}{ Station }} & \multicolumn{7}{c}{ Air temperature $\left.\mathbf{~}^{\mathbf{0}} \mathbf{C}\right)$} \\
\cline { 2 - 7 } & \multicolumn{3}{c}{ Minimum } & \multicolumn{3}{c}{ Maximum } & $\begin{array}{c}\text { Overall } \\
\text { Average }\end{array}$ \\
\cline { 2 - 7 } & Time & Absolute & Mean & Time & Absolute & Mean & 29.1 \\
Mossoró (urban) & $04: 37$ & 23.7 & 24.6 & $12: 51$ & 37.9 & 36.0 & 28.3 \\
Mossoró (rural) & $04: 14$ & 22.7 & 23.8 & $12: 04$ & 36.9 & 35.0 & 30.0 \\
\hline Serra Talhada (urban) & $05: 26$ & 21.5 & 23.1 & $15: 07$ & 39.0 & 37.2 & 29.6 \\
Serra Talhada (rural) & $05: 25$ & 20.8 & 22.0 & $13: 32$ & 38.5 & 36.1 & 28.9 \\
\hline Petrolina (urban) & $05: 23$ & 20.6 & 22.9 & $13: 59$ & 39.0 & 35.9 & 28.1 \\
Petrolina (rural) & $06: 26$ & 20.7 & 22.7 & $16: 17$ & 36.4 & 34.5 & 29.1 \\
\hline Juazeiro (urban) & $07: 01$ & 21.0 & 23.5 & $13: 52$ & 37.1 & 35.1 & 28.8 \\
Juazeiro (rural) & $07: 03$ & 21.1 & 23.5 & $16: 04$ & 36.1 & 34.4 & \\
\hline
\end{tabular}

Table 4 - Relative humidity: minimum (time of occurrence, absolute and average values), maximum (time of occurrence, mean and absolute values) and overall average for the wet period.

\begin{tabular}{|c|c|c|c|c|c|c|c|}
\hline \multirow{3}{*}{ Station } & \multicolumn{7}{|c|}{ Air relative humidity (\%) } \\
\hline & \multicolumn{3}{|c|}{ Minimum } & \multicolumn{3}{|c|}{ Maximum } & \multirow{2}{*}{$\begin{array}{l}\text { Overall } \\
\text { Average }\end{array}$} \\
\hline & Time & Absolute & Mean & Time & Absolute & Mean & \\
\hline Mossoró (urban) & $14: 52$ & 28.3 & 36.0 & $05: 30$ & 80.9 & 78.5 & 61.0 \\
\hline Mossoró (rural) & $14: 09$ & 39.7 & 46.3 & $05: 17$ & 95.4 & 88.3 & 70.6 \\
\hline Serra Talhada (urban) & $14: 33$ & 28.3 & 45.2 & $05: 55$ & 95.0 & 89.5 & 73.0 \\
\hline Serra Talhada (rural) & $12: 28$ & 38.0 & 54.3 & $04: 46$ & 100.0 & 95.6 & 74.0 \\
\hline Petrolina (urban) & $15: 28$ & 23.3 & 38.0 & 07:46 & 9.4 & 87.5 & 62.7 \\
\hline Petrolina (rural) & $16: 24$ & 25.1 & 40.1 & 06:02 & 100.0 & 89.2 & 65.5 \\
\hline Juazeiro (urban) & $15: 12$ & 26.2 & 41.5 & $07: 35$ & 97.1 & 85.8 & 64.6 \\
\hline Juazeiro (rural) & $15: 08$ & 23.7 & 39.8 & 07:29 & 94.8 & 85.2 & 63.8 \\
\hline
\end{tabular}


$\left(\mathrm{RH}_{\mathrm{x}}\right)$ was, on average, lower than $60.0 \%$ in all localities surveyed. The absolute minimum-recorded value was $12.2 \%$ in urban Serra Talhada. In general, the mean values of the climatic variables were lower in the urban than in rural areas of all municipalities. In the Section 2.1 it is possible to evidence that these results are in agreement with the regional climatology.

\subsection{Wind speed}

\section{a) Wet period}

The wind speed is also an important attribute of climate ambience of the urban areas. In general, strong air movements represent a disadvantage in cold climates and effective in warm climates. In the Brazilian semiarid, warm days and calm wind causes quite sharp heat sensation. The wind is a meteorological variable which promotes urban climatic comfort, however, is the element most altered by urbanization (Grimmond, 2007; Runnals and Oke, 2000). The results obtained for this climatic variable are grouped and presented for each study period (Table 6).

For the wet period (Table 6), it was evidenced the occurrence of very weak winds in Mossoró, averaging 0.6 $\mathrm{ms}^{-1}$ in the urban area. Even in the rural area of the city, the average wind speed was relatively low $\left(1.3 \mathrm{~ms}^{-1}\right)$. In Serra Talhada, despite having the same average value of Mossoró $\left(0.6 \mathrm{~m} . \mathrm{s}^{-1}\right)$ during the wet period, there were bursts of $7.0 \mathrm{~ms}^{-1}$ in the urban area. In the rural area of the city, the average wind speed was $1.1 \mathrm{~ms}^{-1}$, very similar to those presented in Mossoró, as well as, showed an absolute maximum value of $6.2 \mathrm{~ms}^{-1}$. The urban area of Petrolina city has shown an average of 1.5 $\mathrm{m} . \mathrm{s}^{-1}$ with absolute maximum value of $8.5 \mathrm{~m} . \mathrm{s}^{-1}$, while the rural area showed an average and absolute maximum values of 3.1 $\mathrm{m} . \mathrm{s}^{-1}$ and $11.2 \mathrm{~m} . \mathrm{s}^{-1}$, respectively. Similarly, the urban area of Juazeiro city presented an average of $1.1 \mathrm{~ms}^{-1}$ with absolute maximum value of $10.0 \mathrm{~ms}^{-1}$, and the rural area an average and absolute maximum value of 3.9 and $12.8 \mathrm{~ms}^{-1}$, respectively. These similar behaviors between Petrolina and Juazeiro can be explained by the proximity between the two cities, i.e., about $4 \mathrm{~km}$ of distance.

\section{b) Dry period}

Table 6 also shows the wind speed values for the dry period. It was observed that the average wind speed of urban area of Mossoró is $1.3 \mathrm{~ms}^{-1}$ and the absolute maximum value

Table 5 - Relative humidity: minimum and maximum (mean and absolute values and times of occurrence) and overall average in the dry season.

\begin{tabular}{|c|c|c|c|c|c|c|c|}
\hline \multirow{3}{*}{ Station } & \multicolumn{7}{|c|}{ Relative humidity (\%) } \\
\hline & \multicolumn{3}{|c|}{ Minimum } & \multicolumn{3}{|c|}{ Maximum } & \multirow{2}{*}{$\begin{array}{l}\text { Overall } \\
\text { Average }\end{array}$} \\
\hline & Time & Absolute & Mean & Time & Absolute & Mean & \\
\hline Mossoró (urban) & $12: 42$ & 23.3 & 32.0 & $05: 31$ & 81.9 & 79.2 & 59.0 \\
\hline Mossoró (rural) & $12: 19$ & 25.1 & 33.6 & 06:00 & 85.8 & 81.6 & 59.7 \\
\hline Serra Talhada (urban) & $15: 36$ & 12.2 & 19.6 & 05:06 & 88.1 & 72.8 & 41.0 \\
\hline Serra Talhada (rural) & $15: 22$ & 15.7 & 23.7 & 06:02 & 89.3 & 73.9 & 47.9 \\
\hline Petrolina (urban) & $15: 28$ & 18.7 & 29.8 & $08: 34$ & 93.1 & 74.6 & 51.7 \\
\hline Petrolina (rural) & $14: 55$ & 21.5 & 28.4 & 06:08 & 100.0 & 77.8 & 52.0 \\
\hline Juazeiro (urban) & 16:04 & 18.3 & 28.6 & $07: 44$ & 91.9 & 70.1 & 48.5 \\
\hline Juazeiro (rural) & $15: 47$ & 17.8 & 28.8 & $07: 36$ & 92.9 & 72.1 & 4.6 \\
\hline
\end{tabular}

Table 6 - Wind speed wet and dry periods: (times of occurrence, absolute and mean values) and and overall averages.

\begin{tabular}{|c|c|c|c|c|c|c|c|c|}
\hline \multirow{3}{*}{ Station } & \multicolumn{8}{|c|}{ Wind speed $\left(\mathrm{m}^{-\mathrm{s}^{-1}}\right)$} \\
\hline & \multicolumn{3}{|c|}{ Wet period } & \multirow[b]{2}{*}{$\begin{array}{c}\text { Overall } \\
\text { Average }\end{array}$} & \multicolumn{3}{|c|}{ Dry period } & \multirow[b]{2}{*}{$\begin{array}{l}\text { Overall } \\
\text { Average }\end{array}$} \\
\hline & Time & $\begin{array}{l}\text { Absolute } \\
\text { maximum }\end{array}$ & Mean & & Time & $\begin{array}{l}\text { Absolute } \\
\text { maximum }\end{array}$ & Mean & \\
\hline Mossoró (Urban) & $15: 00$ & 1.9 & 1.4 & 0.6 & $14: 51$ & 8.8 & 7.1 & 1.3 \\
\hline Mossoró (Rural) & $16: 25$ & 4.8 & 3.8 & 1.3 & $08: 18$ & 8.8 & 7.5 & 3.4 \\
\hline Serra Talhada (Urban) & $07: 54$ & 7.0 & 5.1 & 0.6 & $07: 49$ & 8.5 & 6.9 & 1.4 \\
\hline Serra Talhada (Rural) & $10: 43$ & 6.2 & 5.4 & 1.1 & $06: 45$ & 9.3 & 7.8 & 2.1 \\
\hline Petrolina (Urban) & $19: 42$ & 8.5 & 7.2 & 1.5 & $18: 55$ & 10.3 & 7.0 & 1.1 \\
\hline Petrolina (Rural) & $15: 06$ & 11.2 & 9.9 & 3.1 & $20: 41$ & 13.0 & 10.2 & 2.8 \\
\hline Juazeiro (Urban) & $10: 55$ & 10.0 & 7.7 & 1.1 & $13: 41$ & 10.7 & 7.8 & 1.8 \\
\hline Juazeiro (Rural) & $13: 29$ & 12.8 & 10.8 & 3.9 & $12: 13$ & 14.7 & 10.9 & 3.2 \\
\hline
\end{tabular}


of $8.8 \mathrm{~ms}^{-1}$. In the rural area of the city, the average wind speed was higher than the urban area $\left(3.4 \mathrm{~ms}^{-1}\right)$ and same absolute maximum value. In Serra Talhada, the urban area has showed average wind speed of $1.4 \mathrm{~m} . \mathrm{s}^{-1}$ and absolute maximum value of $8.5 \mathrm{~m} \cdot \mathrm{s}^{-1}$. In the rural area of the city, the average wind speed and absolute maximum values were 2.1 and $9.3 \mathrm{~m} . \mathrm{s}^{-1}$, respectively. The urban area of Petrolina city has shown an average of $1.1 \mathrm{~m} . \mathrm{s}^{-1}$ with absolute maximum value of $10.3 \mathrm{~m} . \mathrm{s}^{-1}$, and the rural area an average and absolute maximum value of $2.8 \mathrm{~m} . \mathrm{s}^{-1}$ and $13.0 \mathrm{~m} . \mathrm{s}^{-1}$, respectively. The urban area of Juazeiro city presented an average of 1.8 $\mathrm{m} . \mathrm{s}^{-1}$ with absolute maximum value of $10.7 \mathrm{~m} . \mathrm{s}^{-1}$, and the rural area showed an average and absolute maximum value of 3.2 and $14.7 \mathrm{~ms}^{-1}$, respectively. It was observed again the similar wind speed behaviors between Petrolina and Juazeiro as discussed previously. It is possible to identify that in the dry period the urban area of Petrolina had the lowest average wind speed $\left(1.1 \mathrm{~m} \cdot \mathrm{s}^{-1}\right)$, while the rural area of Mossoró had the highest average $\left(3.4 \mathrm{~m} . \mathrm{s}^{-1}\right)$. It is also evident that the rural area of all counties showed average wind speed above the respective urban area, thus demonstrating the influence of urban structures on this variable. Thus, the morphology of cities in terms of height, width and density of buildings, affects, besides the standard heating, air movement at street level (Grimmond, 2007) and that the intensity of heat islands decreases with increase in wind speed and cloud cover (Runnals and Oke, 2000).

\subsection{Evaluation of thermal comfort}

\section{a) Wet Period}

The results of thermal discomfort index $\left(\mathrm{DI}_{\mathrm{T}}\right)$ for the wet period (Table 7) showed an uncomfortable condition $\left(\mathrm{DI}_{\mathrm{T}} \geq 26.5\right.$ ${ }^{\circ} \mathrm{C}$ ) in Mossoró on 13, 15 and 23/05/2008 (rural area) and on 25/05/2008 (urban area). These uncomfortable conditions were probably caused by the low wind speed occurred in that wet period (Table 6). The other results indicate a condition of partial comfort $\left(20.0 \leq \mathrm{DI}_{\mathrm{T}} \leq 26.4^{\circ} \mathrm{C}\right)$ for all areas surveyed. The mean values showed no thermal discomfort $\left(15.0 \leq \mathrm{DI}_{\mathrm{T}} \leq 19.9^{\circ} \mathrm{C}\right)$ on any day of the period analyzed. It is also emphasized that the data in Table 7 are daily averages and serve only as indicative of thermal comfort/discomfort situations.

\section{b) Dry period}

In the dry period (Tables 8 and 9) there was a larger partial comfort condition $\left(20.0^{\circ} \mathrm{C} \leq \mathrm{DI}_{\mathrm{T}} \leq 26.4{ }^{\circ} \mathrm{C}\right)$ in all tested areas. The mean values showed no thermal discomfort and/or comfort on any day of the period analyzed. It is also emphasized that the data in Tables 8 and 9 are daily averages and serve only as indicative of thermal comfort/thermal discomfort situations.

It also appears that there are few records of a situation of thermal discomfort. However, this situation stems from the fact that by adopting average values of temperature and relative

Table 7 - Evaluation of thermal discomfort index $\left(\mathrm{DI}_{\mathrm{T}}\right)$ during the wet period (May, 2007). The highlighted values mean uncomfortable conditions

\begin{tabular}{lccccccccccccccc}
\hline \multicolumn{1}{c}{ Station } & $\mathbf{1 2}$ & $\mathbf{1 3}$ & $\mathbf{1 4}$ & $\mathbf{1 5}$ & $\mathbf{1 6}$ & $\mathbf{1 7}$ & $\mathbf{1 8}$ & $\mathbf{1 9}$ & $\mathbf{2 0}$ & $\mathbf{2 1}$ & $\mathbf{2 2}$ & $\mathbf{2 3}$ & $\mathbf{2 4}$ & $\mathbf{2 5}$ & $\mathbf{2 6}$ \\
\hline Mossoró (Urban) & 25.7 & 26.0 & 25.7 & 25.6 & 25.8 & 25.9 & 26.2 & 25.5 & 26.1 & 25.7 & 26,0 & 26.3 & 26.2 & 26.5 & 26.0 \\
Mossoró (Rural) & 26.1 & 26.6 & 26.2 & 26.5 & 26.0 & 26.1 & 26.3 & 26.0 & 26.4 & 25.8 & 25,9 & 26.6 & 26.4 & 26.1 & 26.1 \\
\hline Serra Talhada (Urban) & - & 23.1 & 23.5 & 24.9 & 24.9 & 23.8 & 24.0 & 24.2 & 23.6 & 23.3 & 23,6 & 24.2 & 24.3 & 24.8 & 24.5 \\
Serra Talhada (Rural) & - & 22.6 & 21.8 & 22.3 & 22.6 & 23.6 & 23.8 & 22.8 & 22.9 & 23.0 & 22,6 & 22.3 & 22.5 & 22.9 & 23.5 \\
\hline Petrolina (Urban) & 23.0 & 24.1 & 24.0 & 25.1 & 25.1 & 24.8 & 24.3 & 24.3 & 24.5 & 23.9 & 23,6 & 24.8 & 24.6 & 25.5 & 24.7 \\
Petrolina (Rural) & 22.1 & 23.1 & 23.0 & 24.1 & 24.1 & 23.7 & 23.2 & 23.2 & 23.3 & 22.9 & 22,4 & 23.2 & 22.9 & 24.0 & 23.5 \\
\hline Juazeiro (Urban) & 22.2 & 23.5 & 23.5 & 24.4 & 23.8 & 24.1 & 23.7 & 23.7 & 23.8 & 23.3 & 23,0 & 24.2 & 24.3 & 25.0 & 24.1 \\
Juazeiro (Rural) & 22.2 & 23.2 & 23.1 & 24.0 & 24.1 & 23.8 & 23.3 & 23.3 & 23.4 & 23.0 & 22,6 & 23.7 & 23.8 & 24.7 & 23.7 \\
\hline
\end{tabular}

Table 8 - Evaluation of thermal discomfort index $\left(\mathrm{DI}_{\mathrm{T}}\right)$ during the dry period (November, 2008).

\begin{tabular}{|c|c|c|c|c|c|c|c|c|c|c|c|c|c|c|c|c|}
\hline Station & 15 & 16 & 17 & 18 & 19 & 20 & 21 & 22 & 23 & 24 & 25 & 26 & 27 & 28 & 29 & 30 \\
\hline Mossoró (Urban) & 24.6 & 25.6 & 25.7 & 25.7 & 25.7 & 25.7 & 25.5 & 25.5 & 25.7 & 25.6 & 25.9 & 26.2 & 26.1 & 25.6 & 25.8 & 26.3 \\
\hline Mossoró (Rural) & 25.4 & 25.1 & 25.1 & 25.2 & 25.1 & 25.1 & 24.9 & 24.9 & 25.2 & 25.1 & 25.4 & 25.7 & 25.8 & 25.0 & 25.2 & 25.8 \\
\hline Serra Talhada (Urban) & - & 24.8 & 25.4 & 24.2 & 25.9 & 25.6 & 24.4 & 24.4 & 24.1 & 24.6 & 25.0 & 25.2 & 24.9 & 24.8 & 24.5 & 25.6 \\
\hline Serra Talhada (Rural) & 24.6 & 25.2 & 25.7 & 25.2 & 25.3 & 25.5 & 25.2 & 24.2 & 24.8 & 25.0 & 25.6 & 25.1 & 25.3 & 24.3 & 24.8 & 25.6 \\
\hline Petrolina (Urban) & 25.1 & 24.7 & 25.1 & 25.0 & 25.2 & 25.8 & 25.6 & 25.3 & 24.9 & 24.5 & 24.1 & 25.2 & 25.5 & 24.7 & 24.9 & 24.7 \\
\hline Petrolina (Rural) & 24.4 & 24.0 & $24 . .2$ & 24.1 & 24.4 & 25.2 & 25.1 & 24.7 & 24.5 & 24.1 & 23.5 & 24.6 & 25.1 & 24.1 & 24.3 & 24.3 \\
\hline Juazeiro (Urban) & 24.7 & 24.9 & 23.9 & 25.0 & 25.1 & 25.9 & 25.4 & 25.2 & 24.8 & 24.5 & 24.2 & 25.1 & 25.4 & 24.8 & 25.0 & 24.6 \\
\hline Juazeiro (Rural) & 24.9 & 24.4 & 24.7 & 24.6 & 24.9 & 25.6 & 25.3 & 25.0 & 24.6 & 24.3 & 24.0 & 24.9 & 25.2 & 24.6 & 24.6 & 24.5 \\
\hline
\end{tabular}


Table 9 - Evaluation of thermal discomfort index $\left(\mathrm{DI}_{\mathrm{T}}\right)$ during the dry period (December, 2008).

\begin{tabular}{lccccc}
\hline Station & $\mathbf{0 1}$ & $\mathbf{0 2}$ & $\mathbf{0 3}$ & $\mathbf{0 4}$ & $\mathbf{0 5}$ \\
\hline Mossoró (Urban) & 26.3 & 26.0 & 25.8 & 25.6 & 26.2 \\
Mossoró (Rural) & 25.8 & 25.4 & 25.2 & 24.9 & 25.5 \\
\hline Serra Talhada (Urban) & 25.8 & 25.0 & 24.1 & 25.7 & 25.3 \\
Serra Talhada (Rural) & 25.9 & 25.9 & 24.9 & 24.8 & 26.1 \\
\hline Petrolina (Urban) & 25.9 & 25.3 & 24.0 & 22.7 & 25.4 \\
Petrolina (Rural) & 25.4 & 24.8 & 23.6 & 23.1 & 24.9 \\
\hline Juazeiro (Urban) & 25.9 & 25.3 & 24.1 & 23.1 & 25.5 \\
Juazeiro (Rural) & 25.7 & 25.1 & 23.9 & 25.3 \\
\hline
\end{tabular}

humidity in the calculation of the $\mathrm{DI}_{\mathrm{T}}$ with Thom's equation in its original form. It is possible to minimize the real influence of these variables on the classification of the condition of thermal comfort (Tables 8 and 9). Accordingly, it is proposed to use the related minimum values of maximum temperature and minimum humidity or maximum temperature and maximum humidity for determining the parameters derived from thermal discomfort index proposed by Thom, called $\left(\mathrm{DI}_{\mathrm{T}}\right)_{\mathrm{x}}$ or $\left(\mathrm{DI}_{\mathrm{T}}\right)_{\mathrm{m}}$, respectively. Cities that have not consolidated the urbanization process use to monitor its urban development to prevent the formation of heat islands, promote thermal comfort and improve life quality. This can occur during the environmental licensing of urban allotments and areas of public interest aimed at the implementation of housing programs, with a greater accuracy in choosing the type of flooring to be used in the paving of roads (Bezerra et al., 2013 ).

\section{CONCLUSIONS}

The results of the evaluation of the thermal conditions in urban areas of the Brazilian semiarid region, from data obtained from automatic weather stations installed in wet and dry periods in the municipalities of Mossoró-RN, Serra Talhada and Petrolina-PE and Juazeiro-BA, allow us to formulate the following conclusions:

1) It was shown that naturally there are adverse climatic conditions in the semiarid region, which is potentiated by the constructive elements of the urban spaces, contributing for thermal discomfort of the population;

2) By applying Thom's equation for obtaining the thermal discomfort index $\left(\mathrm{DI}_{\mathrm{T}}\right)$, it was observed that the urban areas reported thermal comfort conditions always inferior to those of the rural area;

3) On the average, thermal discomfort conditions $\left(15.0^{\circ} \mathrm{C} \leq \mathrm{DI}_{\mathrm{T}} \leq 19.9^{\circ} \mathrm{C}\right)$ were observed for some days of the period analyzed. However, the incidence of thermal discomfort related to minimum, average and maximum temperatures, probably associated to the process of planning occupation of their urban space, which have never considered the climatic aspects;

4) Therefore, it can be stated that the Brazilian semiarid region has a specific urban climate, which is influenced by the design characteristics of the urban structure and buildings. This association contributes to the formation of urban heat islands and population thermal discomfort. In addition, the afforestation is an effective mechanism of mitigating the adverse effects of these structures with better life quality of the population.

\section{REFERENCES}

AKBARI, H.; POMERANTZ, M.; TAHA, H. Cool surfaces and shade trees to reduce energy use and improve air quality in urban areas. Solar Energy: v. 70, n. 3, p. 295-310, 2001.

ALEXANDRIA, E.; JONESB, P. Temperature decreases in an urban canyon due to green walls and green roofs in diverse climates. Building and Environments: n. 43, p. 480-493, 2008.

ARMELIN, H. S.; CHERRY, N. Avaliação do uso e desempenho de barreiras de radiação térmica na construção civil. Revista de Ciência e Tecnologia de Materiais de Construção Civil: v. 1, n. 1, p. 79-82, 2004.

AZEVEDO, T. R.; TARIFA, J.R. O ritmo semanal das atividades humanas e o clima da região metropolitana de São Paulo. Laboratório de Climatologia e Biogeografia. Departamento de Geografia, Faculdade de Filosofia, Letras e Ciências Humanas, Universidade de São Paulo, Série TA - Texto 008, 2001.

BARBOSA, R. V. R.; BARBIRATO, G. M.; VECCHIA, F. A. $S$. Vegetação urbana: análise experimental em cidade de clima quente e úmido. ENCAC-COTEDI. Curitiba-PR, Brasil, 5-7 de novembro de 2003.

BEZERRA, P. T. C. A Influência da urbanização no clima das cidades de Petrolina/PE e Juazeiro/BA. Dissertação de Mestrado em Recursos Naturais da Universidade Federal de Campina Grande - PB. Fevereiro, 2009, 115 p. 
BEZERRA, P. T. C.; LEITÃO, M. M. V. B. R.; AZEVEDO, P. V. Ilhas de Calor e Desconforto Térmico no Semiárido Brasileiro: Um Estudo de Caso na cidade de Petrolina-PE. Revista Brasileira de Geografia Física: v. 6, n. 3, p. 427441, 2013.

BLAZEJCZYK, K.; EPSTEIN, Y.; JENDRITZKY, G.; STAIGER, H.; TINZ, B. Comparison of UTCI to selected thermal indices. International Journal of Biometeorology, v.56, p.515-535, 2012.

BURIAN, S. J.; SHEPHERD, J. M. Effect of urbanization on the diurnal rainfall pattern in Houston. Hydrological Processes, v.19, p.1089-1103, 2005.

COLTRI, P. P.; VELASCO, G. D. N.; POLIZEL, J. L.; DEMETRIO, V. A.; FERREIRA, N. J. Ilhas de calor da estação de inverno da área urbana do município de Piracicaba/SP. XIII Simpósio de Sensoriamento Remoto, Florianópolis/SC... Anais: p. 5151-5157, 2007.

CORBELLA, O.; YANNAS, S. Em busca de uma arquitetura sustentável para os trópicos. Rio de Janeiro: Revan, 2003.

GOLDREICH, Y. Urban climate studies in Israel - A review. Atmospheric Environment, v.29, p.467-478, 1995.

GRIMMOND, C.S.B.; ROTH, M.; OKE, T.R.; AU, Y.C.; BEST, M.; BETTS, R.; CARMICHAEL, G.; CLEUGH, H.; DABBERDT, W.; EMMANUEL, R.; FREITAS, E.; FORTUNIAK, K.; HANNA, S.; KLEIN, P.; KALKSTEIN, L.S.; LIU, C.H.; NICKSON, A.; PEARLMUTTER, D.; SAILOR, D. ; VOOGT, J. Climate and More Sustainable Cities: Climate Information for Improved Planning and Management of Cities (Producers/Capabilities Perspective). Procedia Environmental Sciences: v. 1, p. 247-274, 2010.

GRIMMOND, S. Urbanization and global environmental change: local effects of urban warming. The Geographical Journal: v. 173, p. 83-88, 2007.

ICHINOSE, T.; SHIMODOZONO, K.; HANAKI, K. Impact of anthropogenic heat on urban climate in Tokyo. Atmospheric Environment, v.33, p.3897-3909, 1999.

JOHANSSON, E. Influence of urban geometry on outdoor thermal comfort in a hot dry climate: A study in Fez, Morocco. Building and Environment: v. 41, p. 1326-1338, 2006.

KALNAY, E.; CAI, M. Impact of urbanization and land-use change on climate. Nature: v. 432, n. 6939, p. 528-531, 2003.

KITHIIA, J.; DOWLING, R. An integrated city-level planning process to address the impacts of climate change in Kenya: The case of Mombasa. Cities: v. 27, p. 466-475, 2010.

KWOK, A.G. ; CHUN, C. Thermal comfort in Japanese schools. Solar Energy: v.74, p. 245-252, 2003.

LAMBERTS, R. Conforto térmico e stress térmico. Laboratório de Eficiência Energética em Edificações.
Florianópolis - SC, 2014. Disponível em: < http://www. labeee.ufsc.br/sites/default/files/disciplinas/Conforto\%20 T\%C3\%A9rmico\%202014_Com\%20norma.pdf >. Acesso em 22/09/2015.

MILLS; G., CLEUGH,H.; EMMANUEL,R.; ENDLICHER,W.; ERELL,E.; MCGRANAHAN, G.; NG,E.; NICKSON,A.; ROSENTHAL, J.; STEEMER, K. Climate Information for Improved Planning and Management of Mega Cities (Needs Perspective). Procedia Environmental Sciences: v. 1, p. 228-246, 2010.

MONTEIRO, C.A.F.; MENDONÇA, F. (Org.). Clima urbano. São Paulo: Contexto, 2003.

NICOL, J.F.; HUMPHREYS, M.A. Adaptative thermal comfort and sustainable thermal standards for buildings. Energy and building: v. 34, p. 563-572, 2002.

MONTEIRO, L.; ALUCCI, M. Procedimentos para quantificação de variáveis para análise termofisiológica. In: ENCONTRO NACIONAL DE CONFORTO NO AMBIENTE CONSTRUIIDO, 8.; ENCONTRO LATINOAMERICANO DE CONFORTO NO AMBIENTE CONSTRUÍDO, 6., Maceió, 2005. Anais... Maceió: ANTAC, 2005.

OKE, T. R. Canyon geometry and the nocturnal urban heat island: Comparison of scale model and field observations. Journal of Climatology: v. 1, n. 3, p. 237-254, 1991.

OKE, T.R; ZEUNER, G.; JÁUREGUI, E. The Surface Energy Balance in Mexico City. Atmospheric Environments: v. 26B, n. 4, p. 433 - 444, 1992.

PEREZ, J.C; SÁNCHEZ, M.A.V.; BARRADAS, V.L. Clima, urbanización y uso del suelo en ciudades tropicales de Mexico. Ciudades, v. 51, p. 19-24, 2001.

PRADO, R.T.A.; FERREIRA, F.L. Measurement of albedo and analysis of its influence the surface temperature of building roof materials. Energy and Building: v. 37, p. 295-300, 2005.

RUNNALS, K.E., OKE, T.R. Dynamics and control of the near-surface heat Island of Vancouver, British Columbia. Physical Geography: v. 21, n. 4, p. 283-304, 2000.

SARRAT, C.; LEMONSU, A.; MASSON, V.; GUEDALIA, D. Impact of urban heat island on regional atmospheric pollution. Atmospheric Environment, v.40, p.1743-1758, 2006.

SILVA DIAS, M. A. F.; SILVA DIAS, P. L. As incertezas regionais nos cenários de mudanças climáticas globais. Boletim da Sociedade Brasileira de Meteorologia: v. 31, p. 12-17, 2007.

SILVA, V. P. R.; AZEVEDO, P. V.; BRITO, R. S.; CAMPOS, J. H. B. C. Evaluating the urban climate of a typically tropical city of northeastern Brazil. Environmental and Monitoring Assessment, v.161, p.45-59, 2010. 
SOUZA JÚNIOR, I. F. A influência da urbanização no clima da cidade de Campina Grande-PB. Dissertação (Mestrado em Meteorologia). Universidade Federal de Campina Grande, Unidade Acadêmica de Ciências Atmosféricas, Campina Grande, 2006, 86p.

STATHOPOULOS, T.; WU, H.; ZACHARIAS, J. Outdoor human comfort in an urban climate. Building and Environment, v.39, p.297-305, 2004.
VIANA, S.S.M.; AMORIM, M.C.C.T. Caracterização do clima urbano em Teodoro Sampaio-SP: uma introdução. Sociedade \& Natureza: v. 20, n. 2, p. 19-42, 2008. 